\title{
Non-invasive tests of precast cantilever balcony in OWT-67 system
}

\author{
Piotr Bieranowski ${ }^{1, *}$, and Piotr Knyziak ${ }^{1}$ \\ ${ }^{1}$ University of Warmia and Mazury in Olsztyn, Oczapowskiego str. 11, 10-719 Olsztyn, Poland \\ ${ }^{2}$ Warsaw University of Technology, Politechnika sqr. 1, 00-661 Warsaw, Poland
}

\begin{abstract}
This article presents a non-invasive tests report of precast cantilever balcony support in OWT-67 large-panel system. During field testing, the balcony's reinforced concrete structure was subjected to radiometric analysis in the context of thermal energy distribution as well as from the point of view of mycology - to the possible presence of spores of domestic fungi. The temperature distribution tests carried out by means of the electromagnetic wave detection in the infrared spectrum clearly confirmed the significant losses of thermal energy caused by the effect of the thermal constructional bridge located in the balcony. Mycological diagnosis was carried out using the rapid test of the Mycometer bacterial meter, which allows fluorimetric evaluation of the presence of the enzyme presence in filamentous fungi. In the conducted study, no spores of the house mushroom were found on the inside surface of the Z-type balcony supporting beam as a place where condensation of water vapor may occur. The summary also presents a design solution that allows to eliminate this physical problem.
\end{abstract}

\section{Introduction}

Large-panel construction in Poland was designed and implemented at the turn of the 1970s and 1980s [1]. In those years the largest among the various technologies of erecting residential buildings was the construction of large-panel buildings. In 1980, it reached the extreme value of $79 \%$ share of all construction types. The most widespread system among the large-panel systems was OWT-67 - Figure 1. It represented $27.9 \%$ of all erected systems (in all its variants). One of the most problematic structural elements of these buildings were the cantilever balconies (Figure 2).

The construction and technological system of housing construction with the symbol OWT - 67 (version V - Figure 1 and 3) was created as a continuation of the OW - 1700 and OW-1700K systems.

The number in the name of the system reflects the year of the system's creation - 1967, and the abbreviation of the system means: SAVING - LARGE - TYPICAL (in polish: OSZCZĘDNOŚCIOWY - WIELKOPŁYTOWY - TYPOWY). The author's team consisting of: Bacciarelli W., Cygancki J., Frey H., Lachert K., Sadowski Z., set a design

\footnotetext{
* Corresponding author: piotr.bieranowski@uwm.edu.pl
} 
task that was to consist in creating a housing system that would consistently solve the economic aspect together with all requirements normative of that period. The location of the buildings and factories is shown in Figure 4.

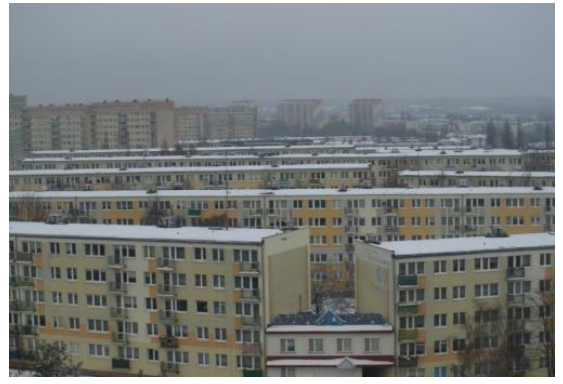

Fig. 1. OWT-67 system (author’s archive)

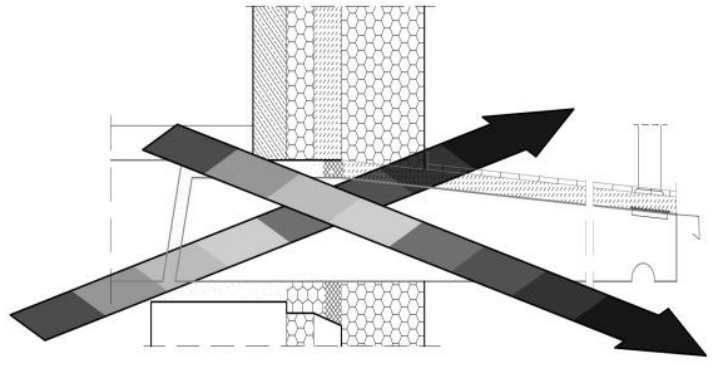

Fig. 2. Heat transfer by cantilevered balcony a)

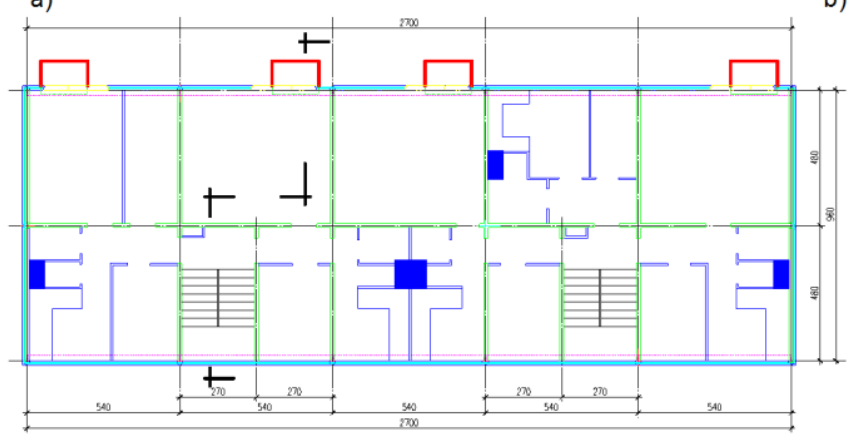

b)

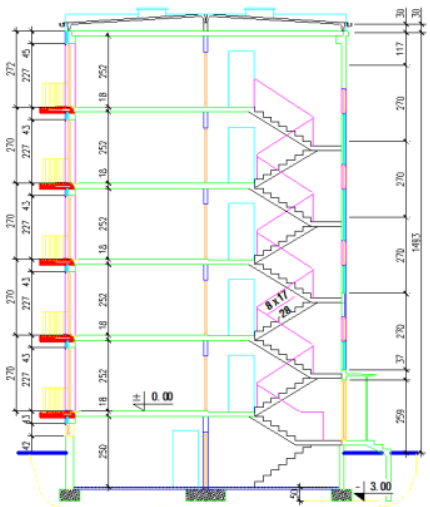

Fig. 3. V-storey building, system OWT-67, a) a floor plan repetitive storey; b) cross-section through the communication and the balcony slab (according to [2], fig. author's archive)
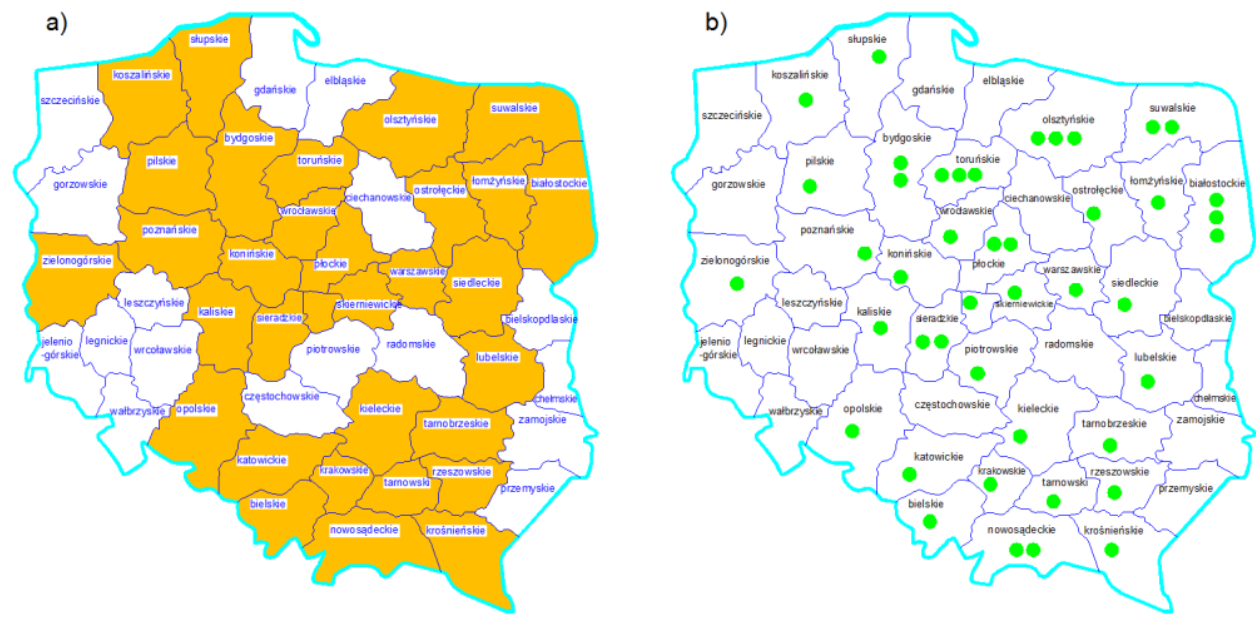

Fig. 4. Location of large-panel construction (a) and factory (b) of the OWT-67 system in the regions of Poland - in voivodships until 1996 (according to [2], fig. author'archive) 
Present criteria of technical basic requirements both national [3] and EU guidelines [4] put a lot of emphasis on reducing the demand of buildings for heat and increasing the use of energy from renewable sources. Large-panel buildings were erected in large numbers in Poland, in the years 1960 - 1985, these were the years when quality was not the main lead, but quantity. The execution also did not always meet the design requirements - the resulting defects and a reduced standard of use of the apartments are currently unacceptable $[5,6]$. Acceptable value of heat transfer coefficient [W / (m2 - K)] [3], decreases and by 2020/21 will be significantly lower.

The process of performing insulation is progressing, its progress is illustrated by the results of inspections carried out in Warsaw. In 2005-06 95 buildings were inspected [8, 9], and in 2016-17 110 [7] buildings were examined. Data regarding large-block and largepanel dwellings and mixed technology (using prefabricated small-size elements and largesize prefabricated roof panels) was collected.

Out of the 110 buildings evaluated, 15 buildings have already been insulated twice (in the 2005-06 inspections, two buildings were already insulated twice, and one had doubleinsulated gable walls). Another 21 buildings have been insulated twice, but the insulation works concerned different parts of the façade. In the case of 59 buildings, works covering the entire building or only gable walls were made once. Only 15 buildings remain noninsulated [7].

\section{Methods}

The research was carried out in the apartment and within the premises of one of the authors and in the neighboring apartment. A methodical approach was used, consisting of three stages, i.e .:

- analysis of project documentation for the OWT-67 system [8],

- literature study in qualitative studies of thermal bridges [9], in the microbiological context

[10] and in architectural and construction terms [2,11,12],

- a diagnostic survey using thermovision [10] and mycological equipment [13].

\subsection{Thermography diagnostics}

Due to the heat loss from the building, the cantilever elements are the most important façade elements (Figure 2). This type of connection in the described OWT-67 system creates a bringing technical problems linear thermal bridge (structural). The tests of the structural thermal bridge of the prefabricated system of the balcony slab of the system were carried out as a thermographic quality assessment [10,14-17].

The diagnostic test was performed with a thermal wave detector with a thermal sensitivity of $50 \mathrm{mK}$ and a measurement accuracy of $\pm 2 \%$. Diagnostics were carried out in full cloud conditions, with an aura of no wind, and there was no atmospheric precipitation. The temperature of the external environment on the test day $T_{e}=258.15 \mathrm{~K}$, internal: level of the ground floor $T_{i}=295.15 \mathrm{~K}$, floor level $T_{i}=292.15 \mathrm{~K}$, and humidity $70 \%$. Emissivity was assumed with the value of $\varepsilon=0.9$ (recommended general value, used for a larger number of analyzed building materials), distance of the measurement site variable, from 1.0 to $3.0 \mathrm{~m}$.

\subsection{Mycological diagnostics}

The phenomenon of thermal bridge, often accompanied by the process of condensation of water vapor on the internal, cooled part of the partition - covering the range of interactions 
of increased thermal losses. The humid environment of the housing together with the medium contained in the building material is a convenient ecosystem for the development of spores of domestic fungi [18-22]. A research analysis using the MycoMeter instrument was carried out for the possible presence of this type of anomaly. It is a patented measuring method for detecting and determining the degree of fungibility on internal surfaces in buildings. It was developed by microbiologists from the University of Copenhagen, cooperating with construction supervision institutions and specialists in the field of antimoulding.

This method is based on fluorimetry detection of the enzyme present in filamentous fungi. MykoMeter is a quantitative method whose results - depending on the density of fungal mass on the surface to be tested - can be divided into three categories A, B, C. The test can be performed in less than an hour, regardless of whether one or twenty samples will be analyzed. Samples are collected by wiping a specific surface moistened with a sterile cotton swab, and then placed in a measuring apparatus and subjected to fluorimetric analysis (Figure 11 and 12). The tests were carried out at room temperature in the winter season.

In the work of the authors, she also found effective use during the in-situ research of the historic wooden structure [23].

\section{Results}

\subsection{Thermal tests results}

The results of in-situ thermovision tests - a linear thermal bridge, which is located in the structural system of the balcony of the large-panel system OWT-67, are shown below (Figures 6, 8 and 10).

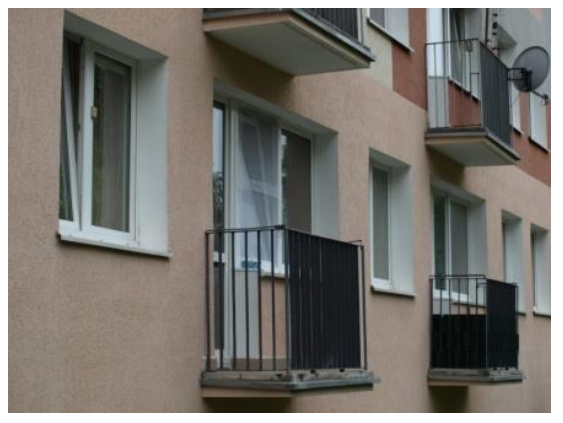

Fig. 5. OWT-67 system (author's archive)

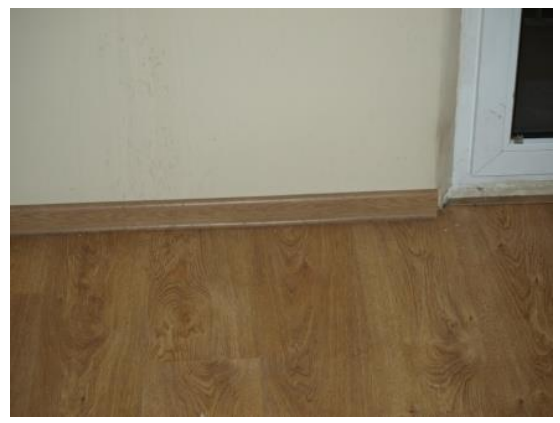

Fig. 7. The floor of the $1^{\text {ST }}$ floor (author's archive)

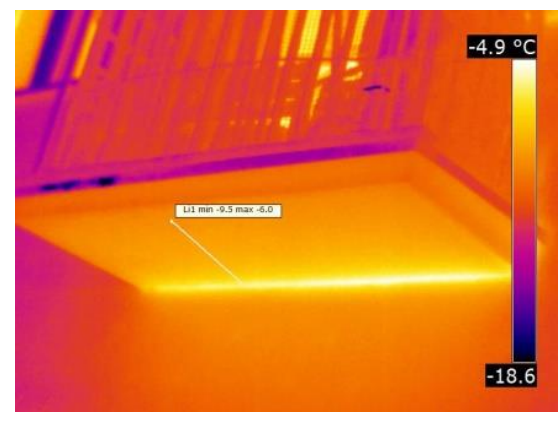

Fig. 6. Slab thermogram

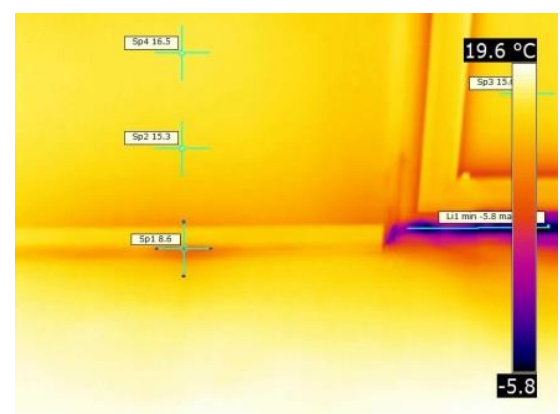

Fig. 8. Thermogram 


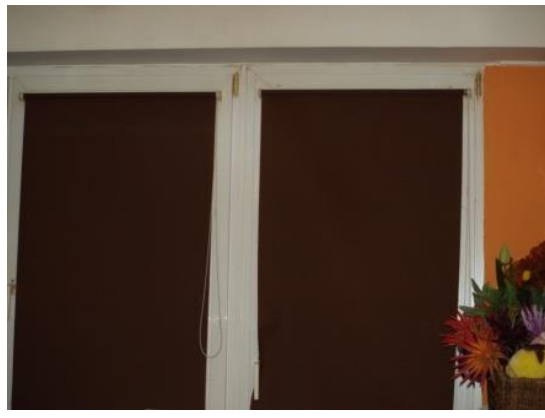

Fig. 9. Lintel ,Z” (author`s archive)

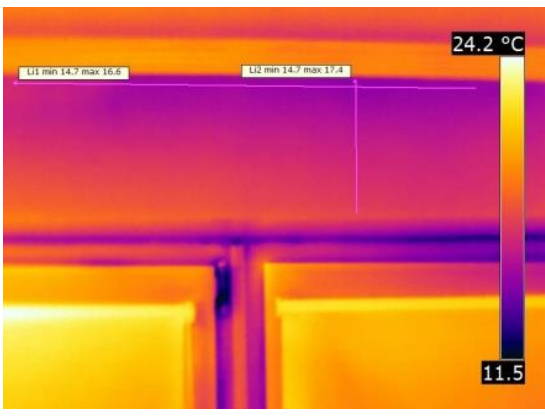

Fig. 10. Thermogram

\subsection{Mycological tests results}

Examination of the fungus potential was done in a large room (Figure 11), for rooms in a small room and kitchen. The results were obtained at the level of category A, which clearly means no spores. The method has three levels of results A, B and C.

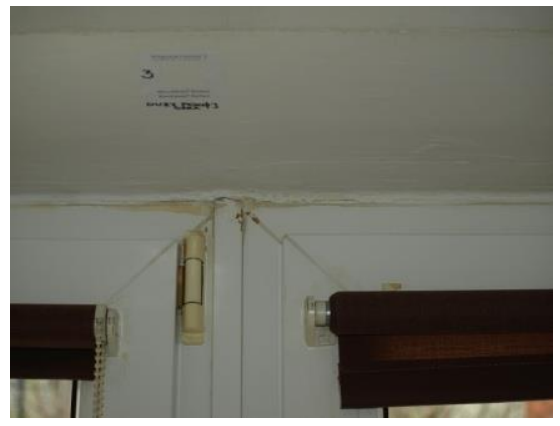

Fig. 11. Measuring point (author's archive)

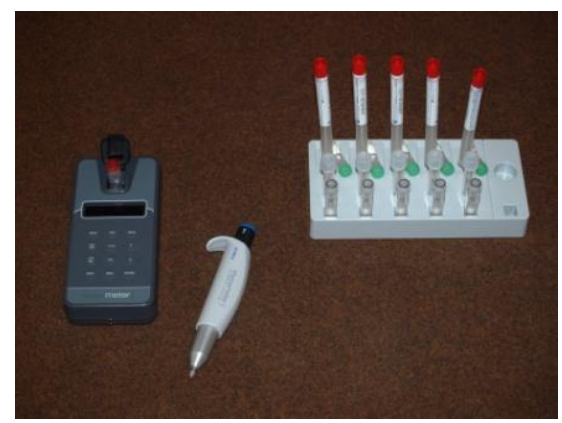

Fig. 12. MycoMeter

\section{Analysis of results}

The conducted tests with the help of wave detection in the infrared spectrum confirmed the significant losses of thermal energy within the linear power bridge. On the external plane of the building envelope, the average temperature difference $\Delta \vartheta_{\mathrm{e}}=4 \mathrm{~K}$ was found - within the interactions and outside the thermal impact area of the thermal bridge (Figure 6). In the aspect of the internal surface of the external wall, the difference was on average $\Delta \theta_{\mathrm{e} 1}=8 \mathrm{~K}$ on the longitudinal wall in the level of the floor (Figure 8) and $\Delta \theta_{\mathrm{e} 2}=3 \mathrm{~K}$ within the prefabricated " $Z$ " lintel beam (Figure 10) - in the level of the roof slab over ground floor.

It is worth emphasizing at this point how important are the acceptance of window joinery with the use of thermovision diagnostics. The lack of this type of thermal technical analysis results in insufficiently good assembly and unnecessary losses of heating energy (Figure 8).

In terms of the tests provided for in the scope of mycology for the possible presence of spores - their presence was not found. However, in many other cases, this type of place, where there is a decrease in surface temperature, condensation of water vapor, favors the development of fungal spores, especially when these places are covered with curtains, curtains. 


\section{Solution of the problem}

A possible alternative solution to the problem discussed above (Figure 13) is the use of the structural system as on Figure 14 [7]. The light balcony system is characterized by a combined steel and reinforced concrete structure, largely independent of the building structure. The structure consists of steel columns, suitably ribbed under the balcony reinforced concrete slab (in order to form a support), supported in four points on the columns. The reinforced concrete slab can be made on the construction site or prefabricated. Due to the amount of work that can be done in the workshop system, work on the construction site while erecting is limited to the assembly minimum. Anchoring to the building structure ensures stability.

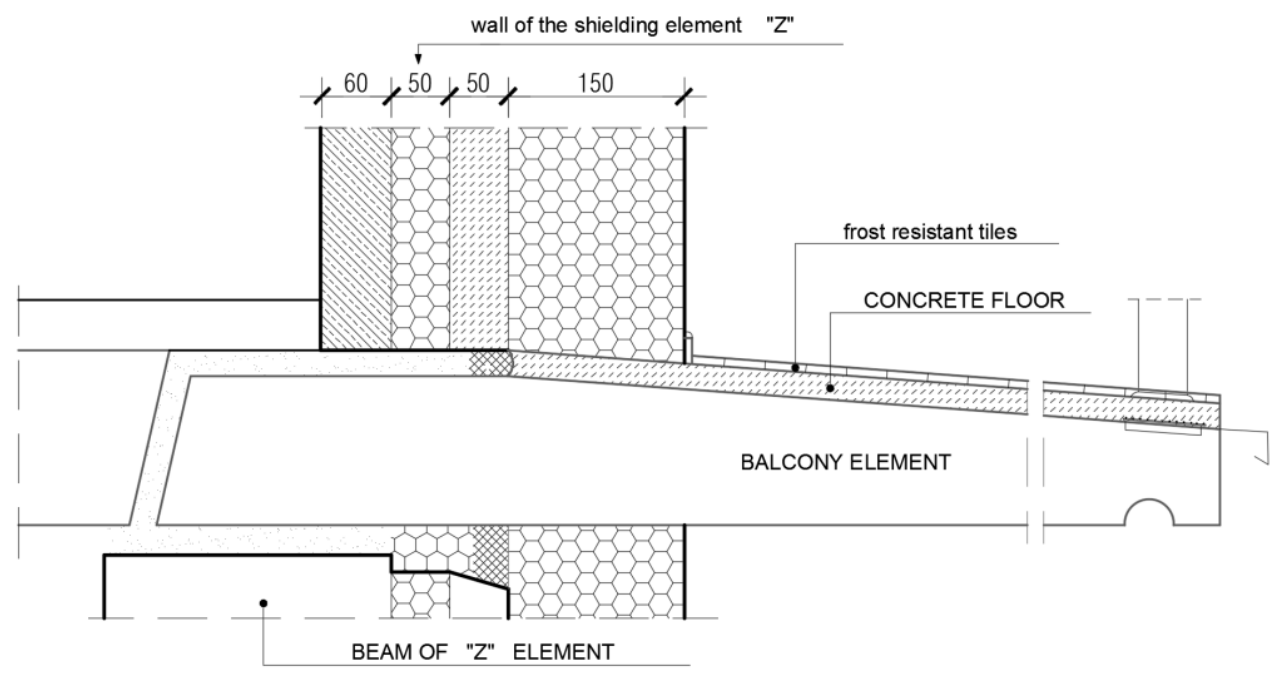

Fig. 13. Existing structure (author`s archive)

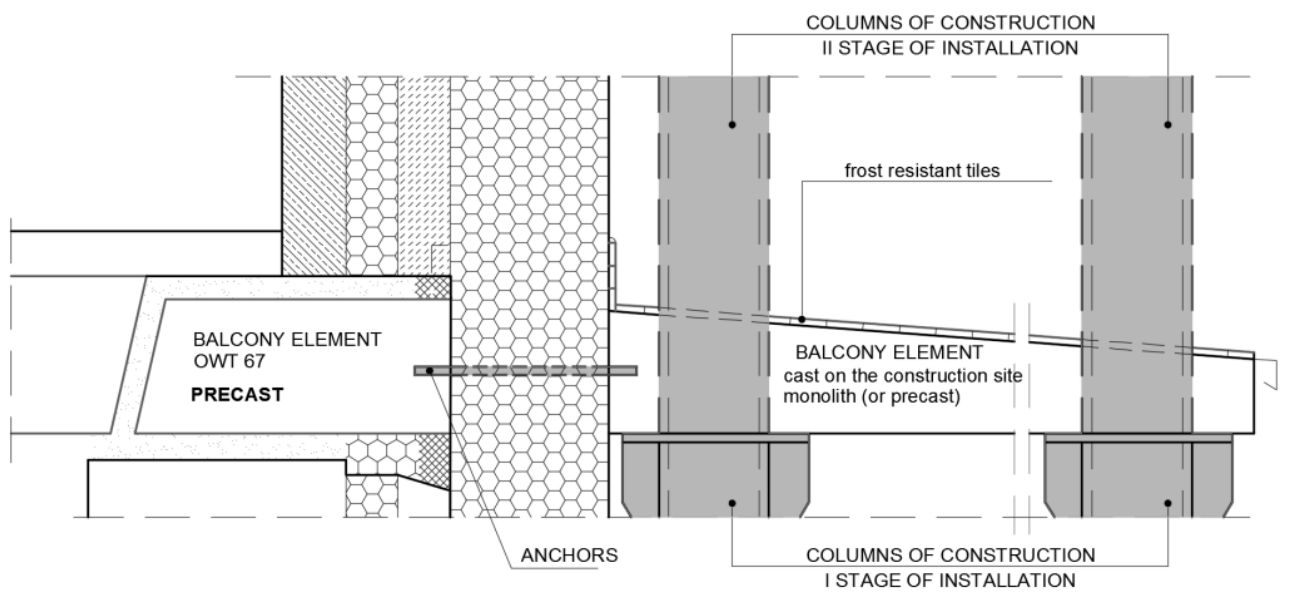

Fig. 14. Convertible project (author`s archive)

\section{Conclusions}

This study is a continuation of research on the phenomenon of thermal bridge in the outer shell of the OWT-67 system contained in [24]. The scale of the problem is significant, as illustrated on fig. 4. 
Proposed thermovision tests with the simultaneous application of fluorimetric analysis is a compatible measurement set, when studying phenomena, so-called thermal bridges (1D, 2D and 3D) and their impact on the possibility of developing fungi on surfaces.

Alternative (author's [24-27] and others) solutions (not met - so far in the literature) eliminating heat losses through structural thermal bridges (structural structures) can be found in literature.

It is also recommended to wider the implementation of thermovision diagnostics to receive assembly of window frames in buildings.

\section{References}

1. Z. Dzierżewicz, W. Starosolski, Systemy budownictwa wielkopłytowego w Polsce w latach 1970 - 1985. Przegląd rozwiązań materiałowych, technologicznych i konstrukcyjnych, Oficyna a Wolters Kluwer business (2010)

2. E. Piliszka, Systemy budownictwa mieszkaniowego i ogólnego - W - 70, Szczeciński, SBO, SBM-75, WUF-T, OWT - 67, WWP, Arkady (1974)

3. Rozporządzenie, Ministra Transportu, Budownictwa i Gospodarki Morskiej z dnia 5 lipca 2013 zmieniające rozporządzenie w sprawie warunków technicznych, jakim powinny odpowiadać budynki i ich usytuowanie. Poz. 926 (2016)

4. Dyrektywa, Parlamentu Europejskiego i Rady Europy z dnia 19 maja 2010 w sprawie charakterystyki energetycznej budynków (tzw. Recast Dyrektywy EPBD)., n.d.

5. P. Knyziak, P. Bieranowski, Imperfekcje w prafabrykowanych budynkach wielkopłytowych, in: B. Goszczyńska (Ed.), Warsztat Pr. Rzeczozn. Bud. XV Konf. Nauk. (2018)

6. P. Knyziak, P. Bieranowski, Imperfekcje pierwotne w budynkach wielkopłytowych, Inżynieria i Bud., 6 (2018)

7. P. Knyziak, J.R. Krentowski, P. Bieranowski, Risks of the Durability of Large-Panel Buildings Elevations in Reference to the Conclusions from Technical Conditions Audits, in: MATEC Web Conf. (2017)

8. Projekt architektoniczno-budowlany budynku przy ul. Dworcowej 45 w Olsztynie., n.d.

9. B. Zyska, Zagrożenia biologiczne w budynku, Arkady, Warszawa (1999)

10. H. Nowak, Zastosowanie badań termowizyjnych w budownictwie, Oficyna Wydawnicza Politechniki Wrocławskiej, Wrocław (2012)

11. B. Lewicki, Budynki mieszkalne z prefabrykatów wielkowymiarowych. Obliczenia i konstrukcja, wyd. II, Arkady (1964)

12. B. Lewicki, Budynki wznoszone metodami uprzemysłowionymi, Arkady (1979)

13. Instrukcja obsługi urządzenia MycoMeter., n.d.

14. E. Lucchi, Applications of the infrared thermography in the energy audit of buildings: A review, Renew. Sustain. Energy Rev., 82 (2018)

15. M. Hurnik, A. Specjal, Z. Popiolek, W. Kierat, Assessment of single-family house thermal renovation based on comprehensive on-site diagnostics, Energy Build., 158 (2018)

16. C.A. Balaras, A.A. Argiriou, Infrared thermography for building diagnostics, Energy Build., 34 (2002)

17. A. Kylili, P.A. Fokaides, P. Christou, S.A. Kalogirou, Infrared thermography (IRT) applications for building diagnostics: A review, Appl. Energy. 134 (2014) 
18. A. Norhidayah, C.K. Lee, M.K. Azhar, S. Nurulwahida, Indoor air quality and sick building syndrome in three selected buildings, Procedia Eng., 53 (2013)

19. J.A. Clarke, C.M. Johnstone, N.J. Kelly, R.C. McLean, J.A. Anderson, N.J. Rowan, J.E. Smith, A technique for the prediction of the conditions leading to mould growth in buildings, Build. Environ., 34 (1999)

20. N. Dujardin, V. Feuillet, D. Garon, L. Ibos, M. Marchetti, L. Peiffer, D. Pottier, V. Séguin, D. Theile, Impacts of environmental exposure on thermal and mycological characteristics of insulation wools, Environ. Impact Assess. Rev., 68 (2018)

21. T. Takigawa, B.L. Wang, N. Sakano, D.H. Wang, K. Ogino, R. Kishi, A longitudinal study of environmental risk factors for subjective symptoms associated with sick building syndrome in new dwellings, Sci. Total Environ., 407 (2009)

22. B. Gutarowska, M. Piotrowska, Methods of mycological analysis in buildings, Build. Environ., 42 (2007)

23. P. Bieranowski, Badanie gotyckiej XIV-wiecznej więźby dachowej integralnie połączonej z hurdycją na zamku w Olsztynie. Nowoczesny aspekt pomiarów w mykologii, Przegląd Bud., 6 (2014)

24. P. Bieranowski, Redukcja mostka cieplnego w istniejącym ustroju konstrukcyjnym poprzez zmianę modelu konstrukcji - balkony, Przegląd Bud., 3 (2015)

25. P. Bieranowski, Alternatywne rozwiązanie konstrukcji komunikacji w pionie w budynkach remontowanych i modernizowanych. Stalowo-betonowa konstrukcja ustroju, Przegląd Bud., 4 (2014)

26. P. Bieranowski, Konstruowanie węzła pasmowego konstrukcji w płaszczyźnie tarczy stropu na przykładzie rozwiązania ustroju balkonu wspornikowego - zespolona konstrukcja żelbetowa, Przegląd Bud., 5 (2015)

27. P. Bieranowski, Ciepłochronna konstrukcja zewnętrznej komunikacji w pionie obiekty wszelkiego przeznaczenia, Przegląd Bud., 9 (2015) 